\title{
Gluten-related disorders and schizophrenia - potential linking mechanisms, diagnostic and therapeutic challenge
}

\author{
Choroby glutenozależne a schizofrenia \\ - potencjalne mechanizmy łączące, możliwości diagnostyczne oraz terapeutyczne
}

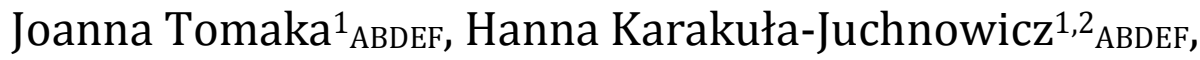 \\ Justyna Morylowska-Topolska ${ }^{2}{ }_{\mathrm{ABDEF}}$, Michał Dzikowski ${ }^{1}{ }_{\mathrm{AB}}$, \\ Dariusz Juchnowicz ${ }^{3}$ DEF, Marta Flis ${ }^{1}{ }_{\mathrm{ABD}}$, Aleksandra Siek ${ }^{1} \mathrm{DEF}$, Michał Próchnicki ${ }^{1}{ }_{\mathrm{DEF}}$
}

1. I Department of Psychiatry, Psychotherapy and Early Intervention, Medical University of Lublin.

2. Department of Clinical Neuropsychiatry, Medical Universtiy in Lublin.

3. Department of Psychiatric Nursing, Medical University of Lublin.

\begin{abstract}
More and more evidence confirms the theory that the intake of cereal products containing gluten may play an important role in the pathogenesis of many diseases. There are also premises indicating the relationship between the so-called gluten-related diseases and the development and course of mental disorders, including schizophrenia.

The aim of this article is to review the literature on the potential relationship between the consumption of gluten and schizophrenia, considering the etiopathogenesis and the role of gluten-free diet in the treatment of schizophrenia.

Methods: There were analysed available research papers in PubMed and Google Scholar with the key words: schizophrenia, gluten-related disorders, allergy to grain products, celiac disease, microbiota, immune system, exorphins and time span: 1960-2016.

Conclusions: Existing research results indicate a possible relationship between diet rich in grain products with high gluten content and the occurrence or exacerbation of schizophrenia symptoms. However, further studies are necessary to: 1) identify groups of patients for whom the consumption of cereal products (gluten) is associated with a particular risk of schizophrenia exacerbation, 2) determine the mechanisms relating the consumption of gluten with the mental state of schizophrenic patients, 3) get the possible benefits of implementing gluten-free diet in patients with schizophrenia.
\end{abstract}

Keywords: schizophrenia, gluten, celiac disease, gluten-related disorders, allergy to gluten.

\section{Streszczenie}

Przybywa dowodów na to, iż w patogenezie wielu chorób istotną rolę może odgrywać spożywanie produktów zbożowych zawierających gluten. Istnieją także przesłanki wskazujące na związek tzw. chorób glutenozależnych z powstawaniem i przebiegiem zaburzeń psychicznych, w tym schizofrenii.

Celem niniejszego artykułu jest przegląd literatury na temat potencjalnego związku pomiędzy spożyciem glutenu a schizofrenią, $\mathrm{z}$ uwzględnieniem etiopatogenezy oraz roli diety bezglutenowej w terapii schizofrenii.

Metoda: Analizie poddano dostępne artykuły z bazy PubMed oraz Google Scholar przy użyciu słów-kluczy: schizofrenia, nadwrażliwość na gluten, alergia na produkty zbożowe, celiakia, mikrobiota, układ immunologiczny, egzorfiny oraz deskryptorów czasowych: 1960-2016 rok.

Wnioski: Dotychczasowe wyniki badań wskazują na możliwy związek diety bogatej w produkty zbożowe z dużą zawartością glutenu na występowanie lub zaostrzanie objawów schizofrenii. Konieczne są jednak dalsze badania celem: 1) identyfikacji grup pacjentów, dla których spożywanie produktów zbożowych (glutenu) wiąże się ze szczególnym ryzykiem pogorszenia przebiegu schizofrenii, 2) ustalenia mechanizmów łączących spożywanie glutenu ze stanem psychicznym pacjentów ze schizofrenią, 3) możliwych korzyści z wdrożenia diety bezglutenowej u pacjentów ze schizofrenią.

Słowa kluczowe: schizofrenia, gluten, celiakia, nadwrażliwość na gluten, alergia na gluten

\section{Introduction}

Gluten is currently one of the most common components of food, included among other things in: wheat, barley groats, rye, and oat grain, barley, spelt and triticale. Grains containing gluten are consumed all over the world, since grain products are the main food of the human population, providing up to $50 \%$ of the caloric intake [1].

The toxic protein fractions of gluten contain gliadins and glutenins, with gliadins consisting of simple proteins and glutenins of the aggregated proteins [2]. The daily 
intake of gluten that causes inflammation within the intestinal mucosa is 10 to $50 \mathrm{mg}$, while the slice of bread contains about $1.6 \mathrm{mg}$ of [3].

The increasing incidence of adverse reactions to gluten and a wide scale of the problem, have made researchers look for answers to the question why this nutrient is toxic for a large number of people [2]. It seems that these changes are driven by a technology process, which has led to the situation in which current market cereals contain more gluten than cereals grown in the past.

\section{Gluten-related diseases}

In 2012, Sapone et al. proposed a new nomenclature of gluten-related disorders, in which, the following disorders were distinguished, depending on the time of formation and the mechanism of reaction to gluten:

- Autoimmune diseases: celiac disease (CD), dermatitis herpetiformis (DH), gluten ataxia (GA)

- Allergic diseases - Wheat Allergy (WA): Food Allergy (FA), Respiratory Allergy, Contact Urticaria and WDEIA (Wheat-Dependent Exercise-Induced Anaphylaxis), and

- Non-Celiac Gluten Sensitivity - (NCGS) [2].

In the next part of the study there will be discussed: celiac disease, allergy to cereal products, and glutenrelated disorders and their potential relationships with the occurrence of schizophrenia.

\section{Celiac disease}

Celiac disease is a disease having immune background characterized by enteropathy occurring in genetically predisposed individuals as a result of ingestion of gluten products [4]. Celiac disease affects about $1 \%$ of the population, is one of common disorders, especially in countries originally inhabited by the European population [2]. It is estimated that per every person diagnosed with celiac disease there are at least 5 people who do not yet have the diagnosis, the majority of which are adults with no symptoms in the gastrointestinal tract [1]. What is more, a general trend of increase in the incidence of the disease in recent decades has been observed. The reasons for this phenomenon are as yet unclear [5,6], but the influence of Western eating habits is suspected as one of the reasons, especially in developing countries [2].

Inflammation in the intestines caused by immune response to gluten causes an increase in IgA antibodies against tissue transglutaminase (TGA), atrophy or flattening of the villi in the mucosa of the duodenum, and the destruction of intercellular tight junctions, which leads to the penetration of antigens and transition of local inflammation into systemic immune response.
The immune response to gluten in the celiac disease is genetically conditioned by the presence of characteristic haplotype HLA -DQ2 and DQ8. Recent GWA (genomewide association) studies have shown the existence of many other loci associated with celiac disease [7].

Initially, abnormal immune response was associated with the early introduction of gluten into the diet of the child, but recent long-term studies have shown that seroconversion to the characteristic of celiac disease immune response (in genetically predisposed indivduals) can occur at any age and is most likely caused by environmental factors $[3,8,9]$.

The factors responsible for the seroconversion rise in the population at risk include: changes in intestinal microbiota, viral infections, and highly processed foods [10].

Celiac disease is a diagnostic challenge for any doctor, because the first symptoms can occur at any age, even in the elderly, and because it is a disease with a very varied clinical picture [1]. Gastrointestinal symptoms often include diarrhea, weight loss, abdominal pain and constipation. Celiac disease is characterized by the presence of rich extraintestinal symptomatology, which shows considerable variability [11]. Extraintestinal manifestations include chronic fatigue, anemia, decreased bone mineral density, high levels of transaminases, joint and muscle pain, spontaneous abortion, peripheral neuropathy [3].

As indicated above, the manifestations of celiac disease have low specificity and sensitivity, in addition, in some persons the symptoms are totally absent $[9,12]$.

It is estimated that the majority of people suffering from celiac disease remains undiagnosed, but despite this, screening is not currently recommended. It is recommended only in children presenting the symptoms similar to the clinical gluten-dependent diseases, with relatives diagnosed with $C D$, as well as in children and young people suffering from celiac disease comorbidities (i.e. diabetes type 1, autoimmune thyroiditis, Down syndrome, herpes dermatitis, psoriasis, IgA deficiency) [11].

All diagnostic tests should be performed in patients keeping to a diet containing gluten to avoid false negative results. It is important that GP ordered diagnostic tests before gluten-free diet is implemented. Genetic tests confirming the presence of HLA-DQ2 and DQ8 are performed to exclude celiac disease. Their presence indicates a predisposition to develop an autoimmune response, but does not provide a basis for the diagnosis of celiac disease.

The determination of IgA antibodies against tissue transglutaminase (IgA-TGA) has the highest sensitivity in the diagnosis of celiac disease [3,13,14]. Measurement of IgA anti-EMA is almost $100 \%$ specific test for confirmation of $\mathrm{CD}$, but it is also an expensive test, so it should be considered as a second-line test [15]. IgG deamidated gliadin peptides (DGP) antibodies, are a useful study in 
IgA-deficient patients and in children under three years of age $[14,16,17]$. Despite the development of serological diagnosis, about $2 \%$ of $C D$ patients remain seronegative, which means that the markers characteristic of celiac disease in them are undetectable [18].

The next diagnostic stage, if serological tests are positive, is the endoscopic test of small intestine and biopsy of duodenal mucosa for histopathological examination. Endoscopic examination should also be performed prior to the exclusion of gluten from the diet [19]. In 2012, the European Society for Pediatric Gastroenterology, Hepatology and Nutrition, published new guidelines for the diagnosis of celiac disease, which questioned the need for histological confirmation of the diagnosis in all children [20]. The new guidelines allow for diagnosis without endoscopy and biopsy of mucosa in children with experienced symptoms, with positive serological tests (more than 10-fold increase in anti-TGA and anti-EMA antibodies), and confirmed presence of HLA-DQ2 / DQ8. In these children, it is necessary to repeat serological tests for observation of a decrease in antibody levels after eliminating gluten from the diet. Such a method of diagnosis allows for diagnosis in patients who present with variations in serological tests, but there are no morphological changes within the intestinal villi. It does not allow, however, for diagnosing children, in whom the disease is asymptomatic [21].

\section{Gluten allergy}

Gluten proteins contained in the cereal grains, also cause an allergic reaction in the mucosa of the intestine, leading to the production of IgE antibodies, resulting in the release of histamine from basophils and mast cells [2]. This type of immune response does not correlate with an increase in TGA (IgA) and EMA (IgA) antibody titers; it does not cause lesions in the intestinal mucosa either, and is not related with the presence of HLA-DQ2 and DQ8. Although a family susceptibility to food allergies has been observed [2].

Depending on the type of allergen exposure, wheat allergy (WA) can be divided into occupational asthma (i.e. baker's asthma) and rhinitis; food allergy (FA), which presents the symptoms on the skin, within the gastrointestinal tract and respiratory tract; wheat - dependent exerciseinduced anaphylaxis (WDEIA) and contact urticaria. These types of allergies can occur in both adults and children [22].

Although sensitivity to grain evaluated on the basis of the presence of IgE antibodies in the blood is more common in adults, children, however, more often suffer from WA $[23,24]$. The symptoms of immediate allergic reaction to food allergens occur mainly in children and tend to fade with age $[25,26]$. The main symptom of WA in children is atopic dermatitis, but the consumption of cereals may also cause typical IgE mediated allergy, i.e.: urticaria, angioedema, bronchospasm, nausea and abdominal pain and in some cases even anaphylactic shock [25]. In adults, the most common form of WA is WDEIA, where the symptoms occur after ingestion of foods containing grains and under the influence of physical activity (as well as after consumption of NSAIDs and alcohol). Gastrointestinal symptoms are uncommon and are moderate in severity, the most common of which are abdominal pain, diarrhea and bloating [22].

In the initial evaluation of a patient with recurrent gastrointestinal symptoms associated with the consumption of gluten, proper procedure consists in making the diagnosis of food allergy. Especially in people who have already been diagnosed with allergies to other foods [2,3]. Such testing should be preceded by a 3 -week period of gluten-free diet, to assess changes in the severity of symptoms, and then gluten should be included again. The main methods of diagnosing allergy include skin prick tests and determination of the IgE antibodies, although their predictive value is only $75 \%$ [2]. Skin test reagents differ in their formula, and also various fractions of proteins in cereals are responsible for allergies. To obtain reliable results, testing should be performed in patients who do not follow a gluten free diet and do not take anti-allergic drugs. Often, however, the final diagnosis is made after the oral, controlled allergen challenge [2].

In contrast to people diagnosed with celiac disease, patients suffering from allergies to cereal proteins can continue consuming them in small quantities, without the occurrence of significant symptoms.

\section{Gluten sensitivity}

NCGS, i.e, Non- Celiac Gluten Sensitivity is a disorder that gives general and / or gastrointestinal symptoms occurring after the ingestion of gluten in patients with excluded diagnosis of celiac disease or food allergy [27]. The existence of this disease was first postulated in 1980 by Cooper et al., who described amelioration of symptoms in 6 out of 8 women in absence of the diagnostic criteria for celiac disease (complaining of bloating, abdominal pain and diarrhea) after gluten withdrawal from the diet $[1,28]$.

NCGS incidence amongst the population is difficult to estimate. Many people not looking for the cause of their ailments, eliminate gluten from the diet, and report the related improvement of well-being. The National Health and Nutrition Examination Survey 2009-2010 says about $0.55 \%$ incidence among the population over 6 years of age, while pointing to a higher incidence in women and older adults [29]. Recent population surveys in the UK show that $13 \%$ of adults report gluten sensitivity $(0.8 \%$ with diagnosed celiac disease), of which $20 \%$ meet the Rome criteria III for irritable bowel syndrome [30]. Allergic tests in these patients are negative, and tTG antibody titer in blood is increased. However, Volta et al., [31] 
found in $25 \%$ of people diagnosed with NCGS elevated levels of gliadins antibodies and deamidated gliadins peptides antibodies. In studies with placebo in 2013, the absence of evidence of gluten specificity and its dose as the only trigger factor of NCGS was demonstrated [32]. The source of similar disorders may be other cereal proteins, FODMAP (fermentable oligosaccharides, disaccharides, monosaccharides and polyols) or inhibitors of amylase/trypsin, whicht are present in pesticides used in crop cultivation [33]. There is no clear evidence that only gluten can cause a clinical picture characteristic of NCGS. More research is needed on the subject [34].

NCGS symptoms are highly variable, partly coinciding with symptoms of $\mathrm{CD}$ and $\mathrm{WA}$, but most of all are similar in nature to the symptoms observed in irritable bowel syndrome (IBS) [9]. The most common symptoms occurring in children are abdominal pain, bowel movements, diarrhea and weakness [35]. These symptoms also occur in adults. In addition, they complain of feeling unwell, fatigue, headaches, anxiety, the so-called foggy mind, joint pain, depressed mood, changes in the skin and allergy symptoms [31]. The most common underlying disease entities in patients with NCGS addressed to the gastroenterologist are: irritable bowel syndrome (47\%), food intolerance (35\%) and allergy (22\%) [31].

NCGS diagnosis should be considered in any person who persistently feels the symptoms associated with the consumption of gluten, and in which the diagnosis of CD and WA was excluded. The purpose of such a diagnosis should be twofold: 1) to determine clinical improvement after eliminating gluten from the diet, 2) observation of the re-introduction of gluten into the diet (after a certain period GFD - gluten-free diet) [27]. This type of diagnostic procedure can be performed only in patients who had not eliminated gluten products from their diet themselves. Currently, the search for biomarkers for the clinical assessment of patients after elimination / re-introduction of gluten has been carried out [27].

\section{Gluten-related diseases and psychiatric disorders}

Celiac disease in its clinical picture is characterized by the presence of abundant extraintestinal symptomatology, which shows considerable variability [11,21,36,].

Many studies have shown a significant remission of symptoms after introduction of a gluten-free diet in schizophrenic patients, in addition to the standard care.

Schizophrenia is a psychiatric disorder that shows a maximum correlation with CD [37]. Already in 1953, Bender noted that children diagnosed with schizophrenia often suffered from CD. In 1961, researchers reported 5 cases of patients suffering from schizophrenia and celiac disease who were admitted to the same hospital within a year [38]. Dohan also published several studies on the relationship between schizophrenia and gluten, the first of which date to 1966. The author showed that the incidence of schizophrenia was lower in areas where there was lower consumption of cereals. He also indicated that a diet free of cereal and milk caused improvement in patients with symptoms of schizophrenia and contributed to a quicker transfer of these patients from closed to open wards (in comparison with the group of patients who consumed cereals and dairy products) [39]. Similar studies confirmed that the hospitalization time in these patients was twice shorter than in patients on a normal diet [40].

In 1997 there was published a case of a woman with schizophrenia in whom celiac disease was diagnosed shortly after admission to a psychiatric hospital. The patient experienced hallucinations and delusions, avolition and thought insertion. In the EEG test, slow recording from the fronto-temporal area was described, while SPECT examination showed a left-sided frontal hypoperfusion. Gluten-free diet was recommended and significant improvement was achieved. After 6 months of GFD, changes visible in the SPECT were absent, as well as remission of psychopathological symptoms was achieved. The patient was allowed to discontinue antipsychotics and remission of symptoms persisted for at least 1 year [41].

In studies using blood samples from the CATIE study, in the same age group the incidence of gliadin antibodies in patients with schizophrenia (23.4\%) and among healthy people (2.9\%) was compared [42]. Other studies have indicated that in people with the first episode of schizophrenia, there are elevated levels of anti-gliadin IgA and IgG, as compared to a healthy control group and a group of chronically ill. Interestingly, patients with the first onset of symptoms had higher levels of antibodies than those chronically ailing [43].

Samaroo in his publication of 2010 compares patients with schizophrenia and patients suffering only from CD. In patients with schizophrenia, there was a poor correlation between the typical markers of celiac disease, i.e. HLA DQ2 and DQ8, anti-TG2 antibodies and anti-DG, and the symptoms. Hence, there is a conclusion that the pathogenesis of sensitivity to gluten in these patients has a different background than in the CD [44].

\section{The mechanisms of action}

Leaky gut syndrome (LGS)

An inseparable element of the theory linking dysfunctions of the gastrointestinal tract with mental disorders is the existence of factors that increase the permeability of both the intestinal wall and the blood-brain barrier. Potential factors causing this phenomenon are stress or inflammation $[45,46,47]$. Antigens entering the digestive system may enter the bloodstream because of a damage of the intestinal epithelium and may selectively vio- 
late the continuity of intercellular connections of tight junction type in the intestines. These junctions are between the epithelial cells that line the lumen of the intestine; similar junctions are located within the blood-brain barrier [48]. In the choroid and the arachnoid plexus, which constitute the blood-brain barrier and the barrier between cerebrospinal fluid and the brain, there are also cellular junctions, the damage of which causes penetration of infectious agents and other active peptides to the CNS [49]. There is evidence that gluten directly increases the production of zonulin, which leads to damage of intercellular tight junctions, thereby increasing the permeability of the intestines, as well as the blood-brain barrier $[3,50,51,52]$. Some bacteria are also a powerful factor triggering the release of zonulin in the intestines [2]. Zonulin is the haptoglobin- 2 precursor, which reversibly changes the permeability of the intestinal wall, being the connection between the bowel diseases with allergic diseases or autoimmune diseases [53].

The autopsy of 82 patients with schizophrenia showed the presence of colitis in $92 \%$, enteritis in $88 \%$, while gastritis in $50 \%[54,55]$. In addition, in patients with schizophrenia there are high levels of intestinal inflammatory markers and bacterial translocation. In treated and untreated patients, increased level of sCD14 was determined, further correlated with high levels of CRP and anti-gluten IgG antibodies, which indicates the relationship with inflammation, increased intestinal permeability and gluten sensitivity [56].

Both the epithelial and endothelial barrier may be affected by intestinal infections of bacterial, viral and parasitic etiology. Exposure to Toxoplasma gondii is a well known risk factor for development of schizophrenia $[57,58,59]$. Inflammation in schizophrenia results from the nonspecific, generalized stimulation of the immune system. It can be expected that the infectious agent will result simultaneously in an increase of antibodies against intestinal tract antigens. Such a relationship was confirmed only in Toxoplasma gondii infection [60]. This relationship was observed particularly in patients with the first episode. This supports the hypothesis that the immune response to the antigen is more important than the exposure itself. There is also evidence that the T. gondii is the direct cause of damage of the intestinal epithelium [61].

\section{The importance of the intestinal microbiome}

Human digestive system is a reservoir of a large number of bacteria that play a role in the absorption of nutrients, body metabolism and functioning of the immune system [62]. Human microbiome consists of about $10^{14}$ cells of bacteria of genus Firmicutes, Bacteroidetes, Actinobacteria, Fusobacteria and Proteobacteria [63]. At various levels of the digestive tract bacteria forming the intestinal flora is different e.g. colon is dominated by
Firmicutes, Bacteroidetes and Actinobacteria [64,65]. The composition of the intestinal microbiome depends on the diet $[65,66,67]$, stress, suffered infections, the hygienic condition and the use of drugs, including antibiotics [68].

Currently, a hypothesis has been put forward that connects the abnormal changes in the intestinal microbiome with inflammation within the gastrointestinal tract [69]. Thus, there is expected a difference in the intestinal microbiome in patients suffering from inflammatory bowel diseases, and the control group $[65,70,71]$. In patients with inflammatory bowel diseases, there is observed a large proportion in the composition of the bacterial flora with the bacteria of genus Firmicutes and the deficincy of bacteria of the genus Bacteroidetes, although a wide variation in the composition of the intestinal flora in patients is noticeable [65].

The mechanism of the influence of intestinal bacteria on the CNS is not known. Until now, several routes connecting the microbiota and the nervous system have been discovered: hormonal (cortisol), immune, metabolic and neuronal routes $[63,72,73]$.

In addition, microbiota affects a wide range of proteins and neurotrophins, i.e. brain derived neurotrophic factor (BDNF), synaptophysin and postsynaptic density 95 protein, which are involved in the development of the CNS and influencing the neuroplasticity. In animals that do not have microbiota, reduced level of BDNF was found, as well as decreased expression of NMDA receptors in the hippocampus and cerebral cortex [74].

Preliminary studies, examining the relationship between microbiota and schizophrenia indicate that both throat flora as well as the intestinal flora, is altered in such patients as compared with healthy controls. Studies to determine the biological and pathological consequences of such changes are still underway [75].

Casein and gluten are not fully digested in some of schizophrenic patients, thereby creating new antigens recognized by the immune system as alien, which is not seen in healthy control subjects [44.76]. Proteases present in the gastrointestinal tract do not fully digest the gluten protein [64]. The analysis of the composition of the bacteria isolated from human stool samples has shown that bacteria of the genus Firmicutes, Actinobacteria, in particular Lactobacillus, Bifidobacterium, are able to fully digest gluten [64]. Moreover, some bioactive peptides, causing inflammation in the intestine in celiac disease were susceptible to digestion by the bacteria Lactobacillus mucosae, L. rhamnosus and Clostridium botulinum / sporogenes [64]. In other studies in the microbiome of the oral cavity there was found bacteria that secreted enzymes capable of digesting gluten (Rothia, Actinomyces, Streptococcus, Neisseria and Capnocytophaga) [77]. This preliminary evidence confirms the relationship be- 
tween the composition of the intestinal microbiome and the individual ability to digest gluten.

\section{Exorphins}

Gluten is digested into hundreds or thousands of fragments, which are subsequently absorbed. Some of them in their structure resemble morphine, therefore were named exorphins (where the prefix "exo" refers to the external origin ) [78].

Exorphins are also formed during the digestion of other proteins e.g. casein, which is present in milk and by its structure, resembles gluten protein, but also rice and maize proteins [79].

Similarly to morphine, exorphins bind to opioid receptors which are distributed throughout the body - in the intestines, the lungs, in the sexual organs and in the variety of locations in CNS. These receptors are dedicated to produced by our body opioids, called endorphins [80].

It is believed that the main function of endorphins is to protect the body against hunger during long periods of food shortage [81,82]. Effects of the opioid may vary, depending on the receptor to which it binds [79]; and the key may be the location of the receptor, whether it is located in the central nervous system or outside of it [82]. By acting to opioid receptors in the intestines, endorphins cause saving of resources of the organism (via constipation and water retention), reduce the locomotor function, the severity of pain, inhibit the production of hormones and reduce the libido. In contrast, by acting on receptors in the brain, they cause an increase in energy expenditure by the body and cause an increase in its activity. Yeomans and Gray in their studies [83] confirmed potential link between the disorder in the functioning of opioid system and eating disorders, such as anorexia.

Exorphins will bind to opiate receptors in the brain, if they cross the blood-brain barrier [84]. The crucial question is whether they cross this barrier in the quantities sufficient to produce the effect. Some authors challenge this thesis, particularly if there is evidence of damage to the blood-brain barrier [85]. But this is not a simple conclusion, when we take into account how easily bloodbrain barrier may be damaged - even by stress [45], diet [86], alcohol [87], and OTC (over-the-counter) drugs [88]. An interesting experiment confirming this thesis is giving to rats by oral gavage the radioactive gluten proteins, which can be found later in the CNS as exorphins [89.90].

Production of exorphins is very effective, for example, the intake of two tablespoons of milk (about $1 \mathrm{~g}$ of casein), causes producing opioids in an amount sufficient to induce physiological effects [91]. This fact is significant, especially as opioids produced from digestion of gluten are stronger than those produced due to digestion of casein [78].
In urine [92] and blood [93] of schizophrenics, elevated levels of exorphins produced from the digestion of milk and gluten, were found [94,95]. These substances administered in the intracerebral injection to rats caused their extremely strange behavior - initially a big anxiety, then decreased activity. Among other things, the rats paid no attention to the ringing bell, as if they were seemingly deaf, similarly to children with autism spectrum disorders [96.97]. In contrast, exorphins from healthy individuals caused weakness in rats, but they did not behave strangely [93].

Apart from provoking behavioral disorders similar to those observed in schizophrenia or autism (i.e. the decline of social activity, reduced sensitivity to pain, uncontrolled motor behavior) [96], exorphins were activating in rats the same centers in the brain that in humans are affected by the disease. The way in which they affect the visual and auditory centers is consistent with their abnormal functioning in schizophrenia (hallucinations) [96]. Therefore, not accidental seems a description of an adult patient who had suffered from auditory and visual hallucinations from childhood until the withdrawal of gluten products from his diet [98].

Exorphins effect on the brain or behavior can be reversed by administration of opioid antagonists [99]. In some cases, naloxone caused complete disappearance of psychotic symptoms, particularly hallucinations in schizophrenia [100].

In children with psychotic symptoms [101], in patients with schizophrenia [102] and women with postpartum psychosis [103] elevated level of exorphins was detected in the cerebrospinal fluid [80]. Physiologically, exorphins should not be here. However, when blood-brain barrier is damaged, exorphins can pass from the intestinal lumen into the bloodstream (where they stimulate the immune system), and then pass into the CSF. It has been shown that in patients with schizophrenia, the higher the level of anti-gluten antibodies was detected in blood, the higher level of them was determined in the CSF [104]. This relationship suggests that in patients the spread of antibodies occurs on a larger scale than in healthy subjects, indicating some subtle, transient disorders of bloodbrain barrier. It is worth mentioning that gluten can cause this type of dysregulation within the blood-brain barrier.

\section{The role of diet in the therapy}

Evidence that a diet free of cereal products (and possibly also dairy products, given the similarity between gluten and casein) may result in remission of symptoms in some mentally ill patients, has been present for about fifty years [80].

In celiac disease, a strictly followed gluten free diet is the only chance of inhibition of autoimmune response. However, individual variability within the tolerance range 
of gluten in WA and NCGS allows for less restrictive approach to diet. Keeping a gluten-free diet is difficult and often patients do not fully comply with the recommendations [105]. FDA in 2013 released standards for food manufacturers and the obligation to indicate /label the products containing gluten. Then the number of glutenfree products has increased significantly [106].

The improvement in mental health in a gluten-free diet will obviously be observed only in patients who show excessive sensitivity to grain products, expressed e.g. in the presence of gliadin antibodies [80]. In a small study on a sample of 8 patients who showed no symptoms of gluten sensitivity, none of them experienced the benefits of a glutenfree and additionally devoid of dairy products diet $[107,108]$. In the descriptions of individual cases of patients who presented symptoms of gluten-dependent disorders, improvement after the introduction of GFD was always observed. Significant improvement was described in two patients with schizophrenia [109], and in two with dementia [110]. Complete remissions were described in three different patients with psychotic symptoms [111,112,113].

Serological markers such as antibodies to tissue transglutaminase and IgE antibodies should return to normal with the consistent application of the gluten-free diet. Signs of consumption of products contaminated with gluten [114] and inadvertent ingestion of gluten in pro- cessed foods and spices [115] will result in a continuous rise in celiac disease markers.

\section{Conclusions}

The future of treatment of gluten-dependent disorders is believed to be in the modification of gluten proteins, supplementation of patients with enzymes and the introduction of polymeric compounds, which are aimed to neutralize the gliadin in the gastrointestinal tract (polimeric binders) $[9,116,117]$.

Introduction of a gluten-free diet generates high costs, and the availability of products is not always easy. It is also hard to get full cooperation, especially among young people. The introduction of an elimination diet should be considered an additional procedure for traditional antipsychotic treatment. It should be considered in patients who present with symptoms of gluten sensitivity or asymptomatic patients so called clinically silent, in whose high antibody levels in blood that correlate with gluten-dependent diseases are determined.

Clinicians need to be very sensitive to the presence of symptoms and other manifestations suggestive of intolerance to gluten, should collect detailed family history of celiac disease and other autoimmune diseases to guide properly for diagnostic tests before exclusion of gluten from the diet [9].

\section{Wstęp}

Gluten jest obecnie jednym z najbardziej rozpowszechnionych składników żywności, zawartym między innymi w: pszenicy, kaszy jęczmiennej, życie, a także ziarnie owsa, jęczmienia, orkiszu oraz pszenżyta. Zboża zawierające gluten są spożywane na całym świecie, ponieważ produkty zbożowe są głównym pożywieniem populacji ludzkiej i pokrywają około $50 \%$ zapotrzebowania kalorycznego [1].

Szkodliwe białkowe frakcje glutenu zawierają gliadynę i gluteninę, gdzie gliadyna składa się z białek prostych , a glutenina ze złożonych [2].

Dzienna podaż glutenu wywołująca zmiany zapalne w obrębie śluzówki jelita to 10 do $50 \mathrm{mg}$, podczas gdy kromka chleba zawiera około 1,6 mg [3].

Wzrastająca częstość występowania niepożądanych reakcji na gluten oraz szeroka skala problemu, sprawiły, że zaczęto szukać odpowiedzi na pytanie dlaczego ten składnik pokarmowy jest toksyczny dla dużej ilości osób [2]. Wydaje się, że zmiany te podyktowane są procesem technologicznym, który spowodował, że obecne na rynku zboża zawierają większą ilość glutenu niż zboża uprawiane dawniej.

\section{Choroby glutenozależne}

W 2012 roku Sapone i wsp. zaproponowali nowy podział chorób glutenozależnych, w którym w zależności od czasu powstania oraz mechanizmu reakcji na gluten wyróżniono:

- Choroby autoimmunologiczne: Celiakię (Celiac disease - CD), opryszczkowe zapalenie skóry (Dermatitis herpetiformis - DH), ataksję glutenozależną (Gluten ataxia - GA),

- Choroby alergiczne - alergię na produkty zbożowe (Wheat allergy - WA): alergię pokarmową (FA), alergię oddechową, pokrzywkę kontaktową oraz WDEIA (pszenico- zależną anafilaksję wywołaną ćwiczeniami)

- oraz nieautoimmunologiczną i niealergiczną nadwrażliwość na gluten (Non-Celiac Gluten Sensitivity - NCGS) [2].

W dalszej części pracy omówione zostaną: celiakia, alergia na produkty zbożowe oraz nadwrażliwość na gluten oraz ich potencjalne związki $\mathrm{z}$ występowaniem schizofrenii.

\section{Celiakia}

Celiakia jest chorobą o podłożu immunologicznym, charakteryzującą się enteropatią powstającą u osób predysponowanych genetycznie, na skutek spożywania produktów zawierających gluten [4]. Na celiakię choruje około $1 \%$ populacji, jest jedną z częściej występujących 
chorób, szczególnie w krajach zamieszkałych pierwotnie przez ludność europejską [2]. Szacuje się, że na każdą osobę ze zdiagnozowaną celiakią przypada co najmniej 5 osób, które jeszcze nie mają postawionej diagnozy, z czego większość to osoby dorosłe bez objawów ze strony przewodu pokarmowego [1]. Co więcej, obserwuje się ogólny trend wzrostu częstości występowania schorzenia w ciągu ostatnich dekad. Przyczyny tego zjawiska są na razie niejasne [5,6], aczkolwiek jako jedną z przyczyn, szczególnie $\mathrm{w}$ krajach rozwijających się podejrzewa się wpływ zachodnich nawyków żywieniowych [2].

Stan zapalny w jelitach, spowodowany odpowiedzią immunologiczną na gluten powoduje wzrost przeciwciał w klasie IgA przeciwko transglutaminazie tkankowej (TGA), zanik lub spłaszczenie kosmków jelitowych w błonie śluzowej dwunastnicy, oraz zniszczenie ścisłych połączeń międzykomórkowych tzw. tight junction, co prowadzi do przenikania antygenów i przejścia miejscowego stanu zapalnego w uogólnioną odpowiedź immunologiczną ustroju.

Odpowiedź immunologiczna na gluten w celiakii jest warunkowana genetycznie poprzez występowanie charakterystycznego haplotypu HLA DQ2 i DQ8. Ostatnie badania GWAS wykazały jednak istnienie wielu innych loci powiązanych z występowaniem celiakii [7]. Początkowo nieprawidłową odpowiedź immunologiczną wiązano z wczesnym wprowadzeniem glutenu do diety dziecka, ale nowsze długoterminowe badania wykazały, że serokonwersja do charakterystycznej dla celiakii odpowiedzi immunologicznej (u osób predysponowanych genetycznie) może wystąpić w każdym wieku i najprawdopodobniej jest wywoływana przez czynniki środowiskowe $[3,8,9]$.

Jako czynniki odpowiedzialne za wzrost serokonwersji w populacji narażonej podaje się: zmiany w mikrobiomie jelitowym, infekcje wirusowe oraz żywność wysoko przetworzoną [10].

Celiakia jest wyzwaniem diagnostycznym dla każdego lekarza, ponieważ pierwsze symptomy mogą pojawić się w każdym wieku, nawet u osób starszych oraz dlatego, że jest to choroba o bardzo różnorodnym obrazie klinicznym [1]. Ze strony przewodu pokarmowego często występujące objawy to: biegunka, utrata wagi, bóle brzucha czy zaparcia. Celiakia cechuje się również występowaniem bogatej symptomatologii pozajelitowej, która wykazuje znaczną zmienność [11]. Objawy pozajelitowe obejmują przewlekłe zmęczenie, anemię, zmniejszoną gęstość mineralną kości, wysokie poziomy aminotransferaz, bóle stawów i mięśni, poronienia samoistne, neuropatię obwodową [3].

Jak wskazano powyżej, zespół objawów występujących w celiakii wykazuje małą swoistość oraz czułość, dodatkowo u części osób objawy w ogóle nie występują $[9,12]$.

Ocenia się, że większość osób chorujących na celiakię nadal pozostaje niezdiagnozowanych, ale mimo to badania przesiewowe nie są obecnie zalecane. Są one rekomendowane jedynie u dzieci: prezentujących objawy zbliżone do obrazu klinicznego chorób glutenozależnych, mających krewnych ze zdiagnozowaną CD, oraz dzieci i młodzieży cierpiących na choroby współwystępujące z celiakią (tj. cukrzyca t.1, autoimmunologiczne zapalenie tarczycy, zespół Downa, opryszczkowe zapalenie skóry, łuszczyca, niedobór IgA ) [11].

Wszystkie badania diagnostyczne powinny być wykonywane u osób pozostających na diecie zawierającej gluten, aby uniknąć wyników fałszywie ujemnych. Ważne jest, aby lekarz pierwszego kontaktu zlecał badania diagnostyczne zanim wdrożona zostanie dieta bezglutenowa. Testy genetyczne potwierdzające obecność HLA DQ2 i DQ8 są wykonywane w celu wykluczenia celiakii. Ich obecność świadczy o predyspozycji do rozwinięcia reakcji autoimmunologicznej, natomiast nie stanowi podstawy do rozpoznania celiakii.

Największą czułość w diagnostyce celiakii wykazuje badanie oznaczenia przeciwciał klasy IgA przeciwko transglutaminazie tkankowej (IgA-TGA) $[3,13,14]$. Pomiar przeciwciał klasy IgA przeciwendomysialnych (EMA) jest prawie w $100 \%$ specyficznym testem dla $C D$, ale jest również drogim badaniem, więc powinno być rozważane jako badanie drugiego wyboru [15]. Przeciwciała w klasie IgG przeciwko deamidowanej gliadynie (DPG), są badaniem użytecznym u pacjentów z niedoborem IgA oraz u dzieci poniżej trzeciego roku życia $[14,16,17]$. Pomimo rozwoju diagnostyki serologicznej około $2 \%$ pacjentów z CD pozostaje seronegatywnymi, co oznacza, że markery charakterystyczne dla celiakii są u nich nieoznaczalne [18].

Kolejnym etapem diagnostycznym, jeśli testy serologiczne są dodatnie, jest wykonanie badania endoskopowego jelita cienkiego i pobranie wycinków błony śluzowej dwunastnicy do badania histopatologicznego. Badanie endoskopowe również należy wykonać przed wyłączeniem glutenu z diety [19]. W 2012 roku European Society for Pediatric Gastroenterology, Hepatology and Nutrition opublikowała nowe wytyczne diagnostyki celiakii, które zakwestionowały konieczność potwierdzenia histopatologicznego rozpoznania u wszystkich dzieci [20]. Nowe wytyczne pozwalają na postawienie diagnozy $\mathrm{z}$ pominięciem badania endoskopowego i pobrania wycinków błony śluzowej u dzieci, u których występowały objawy, z dodatnimi testami serologicznymi (ponad 10krotny wzrost przeciwciał TGA i EMA), i potwierdzoną obecnością HLA DQ2/DQ8. U tych dzieci konieczne jest powtarzanie badań serologicznych, celem obserwacji spadku poziomów przeciwciał po wyeliminowaniu glutenu $\mathrm{z}$ diety. Taki sposób diagnostyki pozwala na postawienie rozpoznania u osób, u których występują odchylenia $w$ badaniach serologicznych, natomiast nie ma zmian morfologicznych w obrębie kosmków jelitowych. 
Nie pozwala on jednak na diagnozowanie dzieci, u których choroba przebiega bezobjawowo [21].

\section{Alergia na gluten}

Białka glutenu zawarte w ziarnach zbóż, wywołują również reakcję alergiczną w śluzówce jelita, prowadzącą do produkcji przeciwciał klasy IgE, powodującą uwalnianie histaminy z bazofilów i mastocytów [2]. Ten rodzaj odpowiedzi immunologicznej nie koreluje ze wzrostem miana przeciwciał TGA (IgA) czy EMA (IgA), nie powoduje również zmian morfologicznych w obrębie śluzówki jelita, a także nie ma związku z występowaniem HLA DQ2 i DQ8. Aczkolwiek jest obserwowana pewna rodzinna skłonność do występowania alergii pokarmowych [2].

W zależności od rodzaju ekspozycji na alergen, WA jest podzielona na astmę zawodową (tzw. baker's asthma) i zapalenie błony śluzowej nosa; alergię pokarmową (FA), która swoje objawy prezentuje na skórze, w obrębie układu pokarmowego oraz oddechowego; pszenicozależną anafilaksję wywołaną ćwiczeniami (WDEIA) oraz pokrzywkę kontaktową. Ten rodzaj alergii może występować zarówno u dorosłych jak i u dzieci [22].

Pomimo, że nadwrażliwość na zboża oceniana na podstawie obecności przeciwciał klasy IgE we krwi, występuje częściej u dorosłych, to jednak dzieci częściej cierpią z powodu WA $[23,24]$. Objawy natychmiastowej reakcji alergicznej na alergeny pokarmowe występują głównie u dzieci i mają tendencję do zanikania wraz $\mathrm{z}$ wiekiem [25,26]. Głównym objawem WA u dzieci jest atopowe zapalenie skóry, ale spożycie zbóż może powodować również typowe IgE zależne reakcje tj.: pokrzywka, obrzęk naczynioruchowy, skurcz oskrzeli, nudności i bóle brzucha, a w niektórych przypadkach nawet wstrząs anafilaktyczny [25]. U dorosłych najczęstszą postacią WA jest WDEIA, gdzie objawy pojawiają się po spożyciu pokarmów zawierających zboża pod wpływem wysiłku fizycznego (a także po NLPZ i alkoholu). Symptomy ze strony układu pokarmowego występują niezbyt często i są umiarkowanie nasilone, najczęstsze z nich to kurczowe bóle brzucha, biegunka i wzdęcia [22].

$\mathrm{W}$ pierwotnej ocenie pacjenta $\mathrm{z}$ nawracającymi objawami ze strony układu pokarmowego, powiązanymi ze spożyciem glutenu, właściwym postępowaniem jest wykonanie diagnostyki alergii pokarmowej. Szczególnie u osób, które mają już zdiagnozowaną alergię na inne pokarmy [2,3]. Takie badania powinny być poprzedzone 3 tygodniowym okresem diety bezglutenowej, żeby ocenić zmiany w nasileniu objawów, a następnie powtórnym włączeniem glutenu. Do głównych metod diagnostycznych alergii zaliczamy punktowe testy skórne oraz oznaczenia poziomu przeciwciał klasy IgE, aczkolwiek ich wartość predykcyjna wynosi tylko 75\% [2]. Reagenty do testów skórnych różnią się między sobą swoją formułą, a ponadto różne frakcje białek zbóż są odpowiedzialne za występowanie alergii. Aby uzyskać wiarygodne wyniki testy należy przeprowadzać u pacjentów, którzy nie stosują diety bezglutenowej oraz nie przyjmują leków antyalergicznych. Często jednak ostateczna diagnoza stawiana jest po doustnej, kontrolowanej prowokacji alergenem [2].

W przeciwieństwie do osób ze zdiagnozowaną celiakią, chorzy cierpiący z powodu alergii na białka zbóż mogą spożywać nadal $\mathrm{w}$ małych ilościach, bez występowania istotnych objawów.

\section{Nadwrażliwość na gluten}

NCGS, czyli Non- celiac gluten sensitivity jest zaburzeniem, dającym objawy ogólne i/lub ze strony układu pokarmowego, występujące po spożyciu glutenu, u osób, u których wykluczono rozpoznanie celiakii lub alergii pokarmowej [27]. Istnienie tego schorzenia pierwszy raz zauważył w 1980 r. Cooper i wsp., który w swojej pracy opisał polepszenie samopoczucia u 6 z 8 kobiet niespełniających kryteriów rozpoznania celiakii (skarżących się na wzdęcia, bóle brzucha oraz biegunki) po wyeliminowaniu z diety glutenu $[1,28]$.

Częstość występowania NCGS wśród populacji jest trudna do oszacowania. Wiele osób nie szukając przyczyny swoich dolegliwości, samodzielnie eliminuje gluten $\mathrm{z}$ diety i relacjonuje związaną $\mathrm{z}$ tym poprawę samopoczucia. The National Health and Nutrition Examination Survey 2009-2010 mówi o 0.55\% częstości wśród populacji powyżej 6 roku życia, wskazując jednocześnie na częstsze występowanie u kobiet i u starszych osób [29]. Ostatnie badania populacji w Anglii wykazały, że $13 \%$ osób dorosłych podaje nadwrażliwość na gluten $(0,8 \%$ z rozpoznaniem celiakii), z czego 20\% spełnia kryteria Rome III zespołu jelita drażliwego [30]. Testy alergiczne u tych pacjentów są ujemne, a miano przeciwciał tTG we krwi nie jest podwyższone. Jednakże Volta wraz ze współpracownikami [31] stwierdził u $25 \%$ osób ze zdiagnozowaną NCGS podwyższony poziom przeciwciał antygliadynowych oraz przeciwciała przeciwko deamidowanym peptydom gliadyny. $\mathrm{W}$ badaniach z placebo z 2013 roku wykazano brak dowodów na specyficzność glutenu i jego dawki, jako jedynego czynnika spustowego NCGS [32]. Źródłem podobnych zaburzeń mogą być inne białka zbóż, FODMAP (fermentable oligosaccharides, disaccharides, monosaccharides and polyols) albo inhibitory amylazy/trypsyny, które występują w pestycydach używanych w uprawie zbóż [33]. Nie ma jednoznacznego dowodu na to, że tylko gluten może wywołać obraz kliniczny charakterystyczny dla NCGS. Potrzebne jest więcej badań na ten temat [34].

Objawy NCGS wykazują dużą zmienność, częściowo pokrywając się z objawami CD oraz WA, ale przede wszystkim mają podobny charakter do objawów 
obserwowanych w zespole jelita drażliwego (IBS) [9]. Zespołem objawów najczęściej występujących u dzieci są bóle brzucha, przelewania, biegunka oraz osłabienie [35]. Objawy te występują również u dorosłych. Dodatkowo skarżą się oni na złe samopoczucie, zmęczenie, bóle głowy, lęk, zamglony umysł (tzw. „foggy mind”), bóle stawów, obniżony nastrój, zmiany skórne i objawy alergii [31]. Najczęściej współistniejącymi jednostkami chorobowymi u pacjentów z NCGS skierowanych do gastrologa są: zespół jelita drażliwego (47\%), nietolerancja pokarmowa (35\%), i alergia (22\%) [31].

Diagnoza NCGS powinna być rozważana u każdej osoby, która stale odczuwa objawy związane ze spożyciem glutenu, a u której wykluczono rozpoznanie CD i WA. Cel takiej diagnozy powinien być dwojaki: 1) ustalenie poprawy klinicznej po wyeliminowaniu z diety glutenu, 2) obserwacja po ponownym wprowadzeniu glutenu do diety (po pewnym okresie GFD- gluten free diet) [27]. Tego typu procedura diagnostyczna może być wykonana tylko u pacjentów, którzy wcześniej samodzielnie nie dokonali eliminacji produktów glutenowych ze swojej diety. Obecnie trwają poszukiwania markerów biologicznych do oceny klinicznej pacjentów po wyeliminowaniu/ponownym wprowadzeniu glutenu [27]

\section{Choroby glutenozależne a zaburzenia psychiczne:}

Celiakia w swym obrazie klinicznym cechuje się również występowaniem bogatej symptomatologii pozajelitowej, która wykazuje znaczną zmienność [11,21,36,].

Wiele badań wykazało znaczną remisję symptomów po wprowadzeniu diety wolnej od glutenu u pacjentów ze schizofrenią, jako dodatku do standardowej opieki.

Schizofrenia jest zaburzeniem psychicznym, które wykazuje największą korelację z CD [37]. Już w 1953 roku, Bender zauważył, że dzieci z rozpoznaniem schizofrenii częściej chorują na CD. W 1961, badacze opisali 5 przypadków pacjentów chorujących na schizofrenię i celiakię, którzy byli przyjęci do tego samego szpitala w ciągu roku [38]. Dohan również opublikował kilka badan na temat powiązań pomiędzy schizofrenią a glutenem, pierwsze z nich pochodzą z 1966 roku. Autor wykazał, że częstość występowania schizofrenii była niższa w rejonach, gdzie mniejsze było spożycie zbóż. Wskazał również, że dieta pozbawiona produktów zbożowych oraz mlecznych powodowała poprawę u pacjentów $\mathrm{w}$ zakresie objawów schizofrenii i przyczyniała się do szybszego przeniesienia tychże pacjentów z oddziałów zamkniętych do otwartych (w porównaniu $\mathrm{z}$ grupa pacjentów spożywajacych zboża i produkty mleczne) [39]. Podobne badania potwierdziły, że czas hospitalizacji tych pacjentów był dwukrotnie krótszy, niż pacjentów pozostających na normalnej diecie [40].
W 1997 opublikowano opis przypadku kobiety chorującej na schizofrenię, u której rozpoznano celiakię zaraz po przyjęciu do szpitala psychiatrycznego. U pacjentki występowały halucynacje, awolicja oraz urojenia nasyłania myśli. W badaniu EEG opisano wolny zapis znad okolicy czołowo-skroniowej, natomiast badanie SPECT wykazało lewostronną hipoperfuzję okolicy czołowej. Zalecono dietę bezglutenową i uzyskano znaczącą poprawę. Po 6 miesiącach GFD zmiany widoczne w SPECT były nieobecne, jak również uzyskano remisję objawów psychopatologicznych. U pacjentki odstawiono leki przeciwpsychotyczne, a remisja objawów utrzymywała się co najmniej 1 rok [41].

W badaniach z użyciem próbek krwi z badań CATIE, w tej samej grupie wiekowej porównano częstość występowania przeciwciał antygliadynowych u osób chorych na schizofrenię $(23,4 \%)$ i wśród osób zdrowych (2,9\%) [42]. Inne badania wskazały, że u osób $\mathrm{z}$ pierwszym epizodem schizofrenii występują podwyższone poziomy przeciwciał antygliadynowych w klasie IgA i IgG, w porównaniu ze zdrową grupą kontrolną oraz grupą osób chorych przewlekle. Co interesujące, pacjenci z pierwszorazowym wystąpieniem objawów mieli wyższe poziomy przeciwciał niż chorujący przewlekle [43].

Samaroo w swojej publikacji z 2010 r. porównuje pacjentów chorujących na schizofrenię i pacjentów chorujących tylko na CD. U pacjentów ze schizofrenią korelacja pomiędzy typowymi markerami dla celiakii, czyli HLA DQ2 i DQ8, przeciwciałami anty- TG2 oraz anty DG, a objawami była słaba. Stąd wniosek, ze patogeneza nadwrażliwości na gluten u tych pacjentów ma inne podłoże niż w CD [44].

\section{Mechanizmy działania}

Zespół przesiąkliwego jelita.

Nieodłącznym elementem teorii łączącej dysfunkcje układu pokarmowego $\mathrm{z}$ chorobami psychicznymi jest istnienie czynników zwiększających przepuszczalność, zarówno ściany jelit, jak i bariery krew-mózg. Potencjalnymi czynnikami powodującymi to zjawisko jest stres czy stan zapalny $[45,46,47]$. Antygeny dostające się do układu pokarmowego mogą przedostawać się do krwioobiegu z powodu istnienia uszkodzeń nabłonka jelitowego, a także mogą selektywnie naruszać ciągłość połączeń międzykomórkowych typu tight junction w jelitach. Połączenia te znajdują się pomiędzy komórkami nabłonkowymi, które wyścielają światło jelit; podobne połączenia międzykomórkowe zlokalizowane są w obrębie bariery krew-mózg [48]. W splocie naczyniowkówym oraz pajęczynówce, które to stanowią barierę krew-mózg oraz barierę pomiędzy płynem mózgowordzeniowym a mózgiem, również znajdują się połączenia 
komórkowe, których uszkodzenie powoduje przedostawanie się do OUNu czynników infekcyjnych i innych aktywnych peptydów [49]. Istnieją dowody na to, że gluten bezpośrednio zwiększa produkcję zonuliny, która doprowadza do uszkodzenia ścisłych połączeń międzykomórkowych typu tight junction, zwiększając tym samym przepuszczalność jelit, a także bariery krew-mózg [3,50,51,52]. Silnym czynnikiem wywołującym uwalnianie zonuliny $\mathrm{w}$ jelitach są również niektóre bakterie [2]. Zonulina jest prekursorem haptoglobiny2, która odwracalnie zmienia przepuszczalność ściany jelit, będąc punktem łączącym choroby jelit $\mathrm{z}$ chorobami alergicznymi czy autoimmunologicznymi [53].

W badaniach autopsyjnych 82 pacjentów chorujących na schizofrenię, wykazano występowanie u 92\% colitis, u $88 \%$ enteritis, natomiast u 50\% gastritis [54,55]. Dodatkowo u pacjentów ze schizofrenią występują wysokie poziomy markerów stanu zapalnego jelit oraz translokacji bakteryjnej. U chorych leczonych oraz nieleczonych oznaczono podwyższony poziom sCD14, dodatkowo skorelowany z wysokim poziomem CRP oraz przeciwciał przeciwglutenowych w klasie IgG, co wskazuje na związek ze stanem zapalnym, zwiększoną przepuszczalnością jelit oraz nadwrażliwością glutenową [56].

Zarówno bariera nabłonkowa, jak i śródbłonkowa mogą być zaburzone przez infekcje jelitowe o etiologii bakteryjnej, wirusowej i pasożytniczej. Narażenie na Toxoplasma gondii jest dobrze znanym czynnikiem ryzyka wystąpienia schizofrenii [57,58,59]. Stan zapalny w schizofrenii wynika z niespecyficznego, uogólnionego pobudzenia układu immunologicznego. Można się spodziewać, że czynnik infekcyjny, będzie powodował jednocześnie wzrost przeciwciał przeciwko antygenom pokarmowym. Taki związek został udowodniony tylko w infekcji Toxoplasma gondii [60]. Ta zależność była obserwowana szczególnie u osób z pierwszym epizodem. To wzmacnia hipotezę, że to odpowiedź immunologiczna na dany antygen jest ważniejsza niż sama ekspozycja. Istnieją również dowody na to, że T. gondii jest bezpośrednią przyczyną uszkodzenia nabłonka jelitowego [61].

\section{Znaczenie mikrobiomu jelitowego}

Ludzki układ pokarmowy jest rezerwuarem dużej liczby bakterii, które odgrywają rolę we wchłanianiu substancji odżywczych, metabolizmie organizmu oraz w funkcjonowaniu układu immunologicznego [62]. Ludzki mikrobiom składa się $\mathrm{z}$ około $10^{14}$ komórek bakterii z rodzaju Firmicutes, Bacteroidetes, Actinobacteria, Proteobacteria i Fusobacteria [63]. Na różnym poziomie układu pokarmowego skład bakterii tworzących florę jelitową jest inny np. w okrężnicy dominują Firmicutes, Bacteroidetes i Actinobacteria [64,65]. Skład mikrobiomu jelitowego jest zależny od diety $[65,66,67]$, stresu, przebytych infekcji, stanu higienicznego, a także stosowanych leków, w tym antybiotyków [68].
Obecnie stawia się hipotezę, która łączy zaburzenia w składzie mikrobiomu jelitowego ze stanem zapalnym w obrębie układu pokarmowego [69]. Zatem spodziewana jest różnica $\mathrm{w}$ mikrobiomie jelitowym u pacjentów cierpiących $\mathrm{z}$ powodu zapalnych chorób jelit, a grupą kontrolną $[65,70,71]$ U pacjentów z chorobami zapalnymi jelit obserwowany jest duży udział w składzie flory bakteryjnej bakterii $\mathrm{z}$ rodzaju Firmicutes oraz niedobór bakterii z rodzaju Bacteroidetes, aczkolwiek zauważalne jest duże zróżnicowanie w składzie flory jelitowej u osób chorych [65].

Mechanizm oddziaływania bakterii jelitowych na OUN nie jest znany. Do tej pory poznano kilka dróg łączących mikrobiota i układ nerwowy: drogę hormonalną (kortyzol), immunologiczną, metaboliczną oraz neuronalną $[63,72,73]$.

Ponadto mikrobiota wpływa na szeroki zakres neurotrofin i białek tj. neurotropowy czynnik pochodzenia mózgowego (BDNF), synaptofizyna i białko 95 gęstości postsynaptycznej, które biorą udział $\mathrm{w}$ rozwoju OUNu oraz wpływają na neuroplastyczność. U zwierząt nie posiadających mikrobioty, stwierdzono obniżony poziom BDNF, a także zmniejszoną ekspresję receptorów NMDA w hipokampie i korze mózgowej [74].

Wstępne badania, badające związek między mikrobiotą a schizofrenią wskazują, że zarówno flora gardłowa, jak i jelitowa jest u tych pacjentów zmieniona w porównaniu do zdrowej grupy kontrolnej. Badania mające na celu ustalić biologiczne i patologiczne konsekwencje takich zmian wciąż trwają [75].

Kazeina i gluten nie są w pełni trawione u części osób chorych na schizofrenię, tworząc tym samym nowe antygeny rozpoznawane przez układ immunologiczny jako obce, czego nie obserwuje się wśród zdrowych osób z grupy kontrolnej $[44,76]$. Proteazy obecne w układzie pokarmowym nie trawią $\mathrm{w}$ pełni białka glutenu [64]. W analizie składu bakterii wyizolowanych z próbek ludzkiego kału, uznano, że zdolne do pełnego trawienia glutenu są bakterie z rodzaju Firmicutes i Actinobacteria, a w szczególności Bifidobacterium i Lactobacillus [64]. Ponadto, niektóre peptydy bioaktywne, wywołujące stan zapalny w jelitach $\mathrm{w}$ celiakii, były wrażliwe na trawienie przez bakterie Lactobacillus mucosae, L. rhamnosus i Clostridium botulinum/sporogenes [64]. Kolejne badania odkryły w mikrobiomie jamy ustnej bakterie, które wydzielają enzymy zdolne do trawienia glutenu (Rothia, Actinomyces, Streptococcus, Neisseria i Capnocytophaga) [77]. Te wstępne dowody potwierdzają zależność pomiędzy składem mikrobiomu jelitowego a indywidualną zdolnością do trawienia glutenu.

\section{Egzorfiny.}

Gluten trawiony jest na setki lub tysiące fragmentów, które nie są później wchłaniane. Niektóre z nich 
swoją budową przypominają morfinę, dlatego zostały nazwane egzorfinami (gdzie przedrostek "egzo" odnosi się do ich zewnętrznego źródła pochodzenia) [78].

Egzorfiny powstają również $\mathrm{w}$ procesie trawienia innych białek np. kazeiny, która występuje w mleku i swoją budową przypomina białko glutenu, ale także białek ryżu i kukurydzy [79].

Podobnie jak morfina, egzorfiny łączą się z receptorami opioidowymi, które rozmieszczone są w całym organizmie - w jelitach, w płucach, w narządach płciowych i różnych lokalizacjach w OUN. Receptory te są dedykowane wytwarzanym przez nasze ciało opioidom, nazywanym endorfinami [80].

Uważa się, iż główną funkcją endorfin jest ochrona organizmu przed głodem, podczas długotrwałych okresów niedostatku żywności $[81,82]$. Działanie opioidu może być różne, w zależności od receptora, z którym się wiąże [79]; a kluczem może być lokalizacja receptora, czy jest on umiejscowiony w OUN czy poza nim [82]. Działając na receptory opioidowe w jelitach, endorfiny powodują oszczędzanie zasobów organizmu (poprzez zaparcia czy zatrzymywanie wody), zmniejszają napęd ruchowy, nasilenie bólu, działają hamująco na produkcję hormonów oraz obniżają libido. Natomiast działając na receptory obecne w mózgu powodują zwiększenie wydatku energetycznego przez organizm oraz powodują wzrost jego aktywności. Potencjalny związek pomiędzy zaburzeniem w funkcjonowaniu układu opioidowego a zaburzeniami odżywiania, takimi jak anoreksja, został potwierdzony w badaniach Yeomans i Gray [83].

Egzorfiny wiążą się $\mathrm{z}$ receptorami opioidowymi w mózgu, jeśli tylko przekroczą barierę krew-mózg [84]. Pytaniem zasadniczym jest czy przekraczają tę barierę w ilościach wystarczających, aby wywołać efekt. Niektórzy autorzy podważają tę tezę, szczególnie, jeśli nie ma dowodów na uszkodzenie bariery krew-mózg [85]. Nie jest to jednak prosty wniosek, biorąc pod uwagę fakt, jak łatwo bariera krew-mózg może być uszkodzona chociażby przez stres [45], dietę [86], alkohol [87], oraz leki OTC (over-the-counter drug) [88]. Ciekawym eksperymentem potwierdzającym tę tezę jest podanie szczurom przez zgłębnik żołądkowy radioaktywnych protein glutenu, które znajdują się później w obrębie OUN w postaci egzorfin [89.90].

Produkcja egzorfin jest bardzo efektywna, na przykład, spożycie dwóch łyżek stołowych mleka (około $1 \mathrm{~g}$ kazeiny) powoduje produkcję opioidów w ilości wystarczającej do wywołania efektów fizjologicznych [91]. Jest to fakt znaczący, szczególnie, iż opioidy powstające $\mathrm{w}$ wyniku trawienia glutenu są silniejsze niż te powstałe w wyniku trawienia kazeiny [78].

W moczu [92] i krwi [93] pacjentów chorych na schizofrenię odkryto podwyższony poziom egzorfin pochodzących z trawienia mleka i produktów glutenowych $[94,95]$. Substancje te podane w iniekcji domózgowej szczurom, powodowały u nich niezwykle dziwne zachowania - początkowo duży niepokój, następnie obniżoną aktywność. Między innymi, szczury nie zwracały uwagi na dzwoniący dzwonek, tak jakby były pozornie głuche, podobnie jak dzieci z zaburzeniami ze spektrum autyzmu [96,97]. Natomiast egzorfiny pochodzące od osób zdrowych powodowały u szczurów osłabienie, ale nie zachowywały się one dziwnie [93].

Poza wywoływaniem zaburzeń zachowania, podobnych do tych obserwowanych w schizofrenii czy autyzmie (tj.:spadek aktywności społecznej, obniżona wrażliwość na ból, niekontrolowane zachowania motoryczne) [96], egzorfiny aktywowały u szczurów te same ośrodki w mózgu, które u ludzi dotknięte są chorobą. Sposób w jaki wpływają na ośrodki wzrokowe i słuchowe jest spójny $z$ ich nieprawidłowym funkcjonowaniem w schizofrenii (halucynacje) [96]. W związku z powyższym, nieprzypadkowy wydaje się opis dorosłego pacjenta, który cierpiał z powodu halucynacji wzrokowych i słuchowych od dzieciństwa, aż do momentu wycofania z jego diety produktów glutenowych [98].

Efekt działania egzorfin na mózg czy zachowanie można odwrócić poprzez podanie antagonistów opioidowych [99]. W niektórych przypadkach nalokson powodował całkowite ustąpienie objawów psychotycznych, szczególnie halucynacji w schizofrenii [100].

U dzieci z objawami psychotycznymi [101], $\mathrm{u}$ chorych na schizofrenię [102] i kobiet z psychozą poporodową [103], wykryto podwyższony poziom egzorfin w płynie mózgowo-rdzeniowym [80]. Fizjologicznie egzorfiny nie powinny tu występować. Jednkaże, gdy bariera krew-mózg jest uszkodzona, egzorfiny mogą przedostawać się ze światła jelit do krwioobiegu (gdzie pobudzają układ immunologiczny), a następnie do CSF. Wykazano, że u chorych na schizofrenię, im wyższy poziom przeciwciał przeciwglutenowych wykrywano we krwi, tym wyższy ich poziom oznaczano w CSF [104]. Ta zależność sugeruje, że u osób chorych rozprzestrzenienie się przeciwciał zachodzi na szerszą skalę niż u osób zdrowych, co wskazuje na pewne subtelne, przemijające zaburzenia bariery krew-mózg. Warto wspomnieć, że gluten może powodować tego typu dysregulację w obrębie bariery krew-mózg.

\section{Rola diety w leczeniu}

Dowody wskazujące na to, że dieta pozbawiona produktów zbożowych (i prawdopodobnie również nabiału, biorąc pod uwagę podobieństwo między glutenem a kazeiną) może powodować remisję objawów u niektórych pacjentów chorych psychicznie, istnieje od około pięćdziesięciu lat [80]. 
W celiakii restrykcyjnie przestrzegana bezglutenowa dieta jest jedyną szansą zahamowania reakcji autoimmunologicznej. Natomiast zmienność osobnicza w zakresie tolerancji glutenu w WA oraz NCGS pozwala na nieco mniej restrykcyjne podejście do diety. Utrzymanie diety bezglutenowej jest trudne i często pacjenci nie stosują się w pełni do zaleceń [105]. FDA w 2013 roku wydało standardy dla producentów żywności i obowiązek oznaczenia produktów zawierających gluten. Wtedy liczba produktów bezglutenowych znacznie wzrosła [106].

Poprawa w zakresie zdrowia psychicznego na diecie bezglutenowej, będzie oczywiście obserwowana tylko u osób, które wykazują nadmierną wrażliwość na produkty zbożowe, wyrażoną np. w obecności przeciwciał antygliadynowych [80]. W małym badaniu na próbie 8 pacjentów, którzy nie wykazywali objawów nadwrażliwości, żaden $\mathrm{z}$ nich nie uzyskał korzyści płynących $\mathrm{z}$ diety bezglutenowej i dodatkowo pozbawionej produktów mlecznych $[107,108]$. W opisach poszczególnych przypadków pacjentów, którzy prezentowali objawy chorób glutenozależnych, poprawa po wprowadzeniu GFD obserwowana była zawsze. Znacząca poprawa opisana została u dwóch pacjentów ze schizofrenią [109] oraz u dwóch z otępieniem [110]. Pełne remisje opisane zostały u trzech różnych pacjentów z objawami psychotycznymi [111,112,113].

Markery serologiczne, takie jak przeciwciała przeciwko tkankowej transglutaminazie oraz przeciwciała klasy IgE powinny wrócić do normy wraz z konsekwentnym stosowaniem diety bezglutenowej. Oznaki spożycia produktów zanieczyszczonych glutenem [114] i nieumyślne spożycie glutenu w żywności przetworzonej oraz przyprawach [115] będzie skutkowało ciągłym wzrostem markerów charakterystycznych dla celiakii.

\section{Podsumowanie}

Przyszłość leczenia chorób glutenozależnych upatruje się w modyfikacji białek glutenu, suplementacji pacjentów enzymami oraz wprowadzeniu polimerowych związków chemicznych, które mają na celu neutralizację gliadyny w przewodzie pokarmowym (polimeric binders) $[9,116,117]$.

Wprowadzenie diety bezglutenowej generuje wysokie koszty, a dostępność produktów nie zawsze jest łatwa. Ciężko również uzyskać pełną współpracę, szczególnie wśród młodzieży. Wprowadzenie diety eliminacyjnej powinno być rozważane jako postępowanie dodatkowe dla tradycyjnego leczenia przeciwpsychotycznego. Należy je rozważyć u osób, u których występują objawy nadwrażliwości na gluten lub u pacjentów bez objawów tzw. niemych klinicznie, u których we krwi oznaczane są wysokie poziomy przeciwciał korelujących z chorobami glutenozależnymi.
Klinicyści muszą być bardzo uwrażliwieni na występowanie objawów i innych manifestacji mogących wskazywać na nietolerancję glutenu, zebrać dokładny wywiad rodzinny w kierunku występowania celiakii i innych chorób autoimmunologicznych, aby odpowiednio kierować na badania diagnostyczne przed wykluczeniem glutenu z diety [9].

\section{Conflict of interest}

The authors have declared no conflict of interest.

\section{References:}

1. Tovoli F., Masi C., Guidetti E., Negrini G., Paterini P., Bolondi L.. Clinical and diagnostic aspects of gluten related disorders. World J Clin Cases. 2015;3(3):275-84.

2. Sapone A., Bai J. C., Ciacci C., Dolinsek J., Green P.H.R., Hadjivassiliou, et al. Spectrum of gluten-related disorders: Consensus on new nomenclature and classification. BMC Med. 2012;10:13.

3. Fasano A., Catassi C. Celiac disease. N Eng J of Med. 2012; 367(25): 2419-2426.

4. Jackson Allen PL.. Guidelines for the diagnosis and treatment of celiac disease in children. Pediatr Nurs. 2004; 30(6): 473-476.

5. Catassi C, Gobellis G. Coeliac disease epidemiology is alive and kicking, especially in the developing world. Dig Liver Dis. 2007;39:908-910.

6. Catassi C., Kryszak D., Louis-Jacques O., Duerksen DR., Hill I., Crowe SE. et al. Detection of Celiac disease in primary care: a multicenter case-finding study in North America. Am J Gastroenterol. 2007;102:1454-1460

7. Lebwohl, B., Ludvigsson, J.F., \& Green, P.H.R. The unfolding story of celiac disease risk factors. Clin Gastroenterol Hepatol. 2014; 12(4): 632-635.

8. Catassi C., Kryszak, D., Bhatti, B., Sturgeon, C., Helzlsouer, K., Clipp, S.L., Fasano A. Natural history of celiac disease autoimmunity in a USA cohort followed since 1974. Ann Med. 2010; 42(7): 530-538.

9. Allen PJ. Gluten-Related Disorders: Celiac Disease, Gluten Allergy, Non-Celiac Gluten Sensitivity. Pediatr Nurs. 2015;41(3):146-50.

10. Troncone, R., \& Discepolo, V..Celiac disease and autoimmunity. J Pediatr Gastroenterol Nutr.2014; 59(Suppl. 1):S9-S11

11. Tack G.J., Verbeek W.H.M., Schreurs M.W.J., \& Mulder C.J.J. The spectrum of celiac disease: Epidemiology, clinical aspects and treatment. Nat Rev Gastroenterol Hepatol. 2010; 7(4): 204-213.

12. Rosén A., Sandström O., Carlsson A., Högberg L., Olén O., Stenlund H., \& Ivarsson A. Usefulness of symptoms to screen for celiac disease. Pediatrics. 2014;133(2): 211-218.

13. Kaukinen K., Lindfors K., Collin P., Koskinen O., Mäki M.. Coeliac disease-a diagnostic and therapeutic challenge. Clin Chem Lab Med. 2010 ;48(9):1205-16.

14. Leffler DA, Schuppan D. Update on serologic testing in celiac disease. Am J Gastroenterol. 2010;105(12):2520-4

15. Husby S., Koletzko S., Korponay-Szabó I.R., Mearin M.L., Phillips A., Shamir R., Zimmer K.P.. European society for pediatric gastroenterology, hepatology, and nutrition guidelines for the diagnosis of coeliac disease. RPIA. 2012;20(3): 227-228.

16. Amarri S., Alvisi P., De Giorgio R., Gelli MC., Cicola R., Tovoli F., Sassatelli R., Caio G., Volta U.. Antibodies to deamidated gliadin 
peptides: an accurate predictor of coeliac disease in infancy. J Clin Immunol. 2013;33(5):1027-30.

17. Zevit N., Shamir R.. Diagnosis of celiac disease: where are we heading after the ESPGHAN 2012 guidelines?. J Pediatr Gastroenterol Nutr. 2014;59 Suppl 1:S13-5.

18. Volta U., Villanacci V.. Celiac disease: diagnostic criteria in progress. Cell Mol Immunol. 2011;8(2):96-102.

19. Hill I.D., Dirks M.H., Liptak G.S., Colletti R.B., Fasano A., Guandalini S., Seidman, E.G.. Guideline for the diagnosis and treatment of celiac disease in children: Recom mendations of the North American society for pediatric gastroenterology, hepatology and nutrition. J Pediatr Gastroenterol Nutr. 2005; 40(1): 1-19.

20. Husby S., Koletzko S., Korponay-Szabó IR., Mearin ML., Phillips A., Shamir R., et al. European Society for Pediatric Gastroenterology, Hepatology, and Nutrition guidelines for the diagnosis of coeliac disease. J Pediatr Gastroenterol Nutr. 2012;54(1):136-60.

21. Guandalini S., \& Vallee P.A.. Pediatric celiac disease. 2010. Retrieved from http://emedicine.medscape.com/article/ 932104overview

22. Elli L., Branchi F., Tomba C., Villalta D., Norsa L., Ferretti F., Roncoroni L., Bardella MT.. Diagnosis of gluten related disorders: Celiac disease, wheat allergy and non-celiac gluten sensitivity. World J Gastroenterol. 2015 ;21(23):7110-9.

23. Vierk KA., Koehler KM., Fein SB., Street DA.. Prevalence of selfreported food allergy in American adults and use of food labels. J Allergy Clin Immunol. 2007;119(6):1504-10.

24. Matricardi PM., Bockelbrink A., Beyer K., Keil T., Niggemann B., Grüber C., Wahn U., Lau S.. Primary versus secondary immunoglobulin E sensitization to soy and wheat in the MultiCentre Allergy Study cohort. Clin Exp Allergy. 2008;38(3):493-500.

25. Ramesh S. Food allergy overview in children. Clin Rev Allergy Immunol. 2008;34(2):217-30

26. Keet CA., Matsui EC., Dhillon G., Lenehan P., Paterakis M., Wood RA. The natural history of wheat allergy. Ann Allergy Asthma Immunol 2009;102(5):410-5. doi: 10.1016/S10811206(10)60513-3

27. Catassi C., Elli L., Bonaz B., Bouma G., Carroccio A., Castillejo G., et al. Diagnosis of Non-Celiac Gluten Sensitivity (NCGS): The Salerno Experts' Criteria. Nutrients. 2015;7(6):4966-77.

28. Cooper BT., Holmes GK., Ferguson R., Thompson RA., Allan RN., Cooke WT. Gluten-sensitive diarrhea without evidence of celiac disease. Gastroenterology. 1980; 79: 801-806

29. Digiacomo, D.V., Tennyson, C.A., Green, P.H., \& Demmer, R.T. Prevalence of gluten-free diet adherence among individuals without celiac disease in the USA: Results from the continuous national health and nutrition examination survey 2009-2010. Scand J Gastroenterol. 2013; 48(8):921-925.

30. Aziz I., Lewis N.R., Hadjivassiliou M., Winfield S.N., Rugg N., Kelsall A., Nevrick L., Sanders D.S. A UK study assessing the population prevalence of self-reported gluten sensitivity and referral characteristics to secondary care. Eur J Gastroenterol Hepatol . 2014; 26(1): 33-39.

31. Volta U., Bardella MT., Calabrò A., Troncone R., Corazza GR.. Study Group for Non-Celiac Gluten Sensitivity. An Italian prospective multicenter survey on patients suspected of having non-celiac gluten sensitivity. BMC Med. 2014;12:85.

32. Biesiekierski J.R., Peters S.L., Newnham E.D., Rosella O., Muir J.G., \& Gibson P.R. No effects of gluten in patients with self-reported non-celiac gluten sensitivity after dietary reduction of fermentable, poorly absorbed, short-chain carbohydrates. Gastroenterology. 2013; 145(2): 320-328.e1-3.
33. Vazquez-Roque M., Oxentenko AS. Nonceliac Gluten Sensitivity. Mayo Clin. Proc.. 2015; 90(9):1272-7.

34. Lundin K.E.A., \& Alaedini A.. Non-celiac gluten sensitivity. Gastrointestinal Gastrointest Endosc Clin N Am. 2012;22(4):72334.

35. Catassi. C., Bai J.C., Bonaz B., Bouma G., Calabrò A., Carroccio A., Fasano A. Non-celiac gluten sensitivity: The new frontier of gluten related disorders. Nutrients. 2013; 5(10), 3839-3853.

36. Newton KP., Singer SA. Celiac disease in children and adolescents: special considerations. Semin Immunopathol. 2012;34(4):47996.

37. Kalaydjian AE., Eaton W., Cascella N., Fasano A. The gluten connection: The association between schizophrenia and celiac disease. Acta Psychiatr Scand. 2006; 113:82-90.

38. Graff H., Handford A. Celiac syndrome in the case histories of five schizophrenics. Psychiatr Q. 1961; 35:306-313.

39. Dohan FC., Grasberger JC., Lowell FM., Johnston HT Jr, Arbegast AW. Relapsed schizophrenics: More rapid improvement on a milk- and cereal-free diet. Br J Psychiatry. 1969; 115:595-596.

40. Dohan FC., Grasberger JC. Relapsed schizophrenics: Earlier discharge from the hospital after cereal-free, milk-free diet. Am J Psychiatry. 1973; 130:685-688.

41. De Santis A., Addolorato G., Romito A., Caputo S., Giordano A., Gambassi G., Taranto C., Manna R., Gasbarrini G. Schizophrenic symptoms and SPECT abnormalities in a coeliac patient: regression after a gluten-free diet. J Intern Med. 1997;242(5):421-3.

42. Cascella NG., Kryszak D., Bhatti B., Gregory P., Kelly DL., Mc Evoy JP., et al. Prevalence of celiac disease and gluten sensitivity in the United States clinical antipsychotic trials of intervention effectiveness study population. Schizophr Bull. 2011; 37:94-100.

43. Dickerson F., Stallings C., Origoni A., Vaughan C., Khushalani S., Leister $F$. et al. Markers of gluten sensitivity and celiac disease in recent-onset psychosis and multi-episode schizophrenia. Biol Psychiatry 2010; 68: 100-104.

44. Samaroo D., Dickerson F., Kasarda DD., Green PH., Briani C., Yolken RH., et al. Novel immune response to gluten in individuals with schizophrenia. Schizophr Res. 2010; 118:248-255.

45. Söderholm J.D., and Perdue M.H. II.Stress and intestinal barrier function. Am J Physiol. Gastrointest Liver Physiol. 2001; 280:G7-G13.

46. Collins SM., Bercik P. The relationship between intestinal microbiota and the central nervous system in normal gastrointestinal function and disease. Gastroenterology. 2009;136(6):2003-14.

47. Lambert GP. Stress-induced gastrointestinal barrier dysfunction and its inflammatory effects. J Anim Sci. 2009;87(14 Suppl):E101-8.

48. Jong A, Huang SH. Blood-brain barrier drug discovery for central nervous system infections. Curr Drug Targets Infect Disord. 2005;5(1):65-72.

49. Laterra J., Keep R., Betz LA., and Goldstein GW. BloodCerebrospinal Fluid Barrier In Basic Neurochemistry: Molecular, Cellular and Medical Aspects. 6th edition. Siegel GJ, Agranoff BW, Albers RW, editors. Philadelphia: Lippincott-Raven; 1999.

50. Clemente MG., De Virgiliis S., Kang JS., Macatagney R., Musu MP., Di Pierro MR., Drago S., Congia M., Fasano A. Early effects of gliadin on enterocyte intracellular signalling involved in intestinal barrier function. Gut. 2003;52(2):218-23.

51. Thomas KE., Sapone A., Fasano A., Vogel SN. Gliadin stimulation of murine macrophage inflammatory gene expression and intestinal permeability are MyD88-dependent: role of the innate immune response in Celiac disease. J Immunol. 2006 ;176(4):2512-21.

52. Lammers KM., Lu R., Brownley J., Lu B., Gerard C., Thomas K., Rallabhandi P., Shea-Donohue T., Tamiz A., Alkan S., Netzel-Arnett 
S., Antalis T., Vogel SN., Fasano A. Gliadin induces an increase in intestinal permeability and zonulin release by binding to the chemokine receptor CXCR3. Gastroenterology. 2008;135(1):194-204.e3.

53. Tripathi A., Lammers KM., Goldblum S., Shea-Donohue T., NetzelArnett S., Buzza MS., Antalis TM., Vogel SN., Zhao A., Yang S., Arrietta MC., Meddings JB., Fasano A. Identification of human zonulin, a physiological modulator of tight junctions, as prehaptoglobin-2. Proc Natl Acad Sci U S A. 2009;106(39):16799804. doi: 10.1073/pnas.0906773106.

54. Buscaino V. Patologia extraneurale della schizofrenia. Fegato, tubo digerente, sistema reticolo endoteliale. Acta Neurol. 1953; 8: 1-60.

55. Hemmings G. Schizophrenia. Lancet 2004; 364(9442): 13121313.

56. Severance EG., Gressitt KL., Stallings CR., Origoni AE., Khushalani S., Leweke FM. et al. Discordant patterns of bacterial translocation markers and implications for innate immune imbalances in schizophrenia. Schizophr. Res. 2013; 148(1-3): 130-137.

57. Mortensen PB., Nørgaard-Pedersen B., Waltoft BL., Sørensen TL., Hougaard D., Yolken RH. Early infections of Toxoplasma gondii and the later development of schizophrenia. Schizophr Bull. 2007;33(3):741-4.

58. Torrey EF., Bartko JJ., Lun ZR., Yolken RH. Antibodies to Toxoplasma gondii in patients with schizophrenia: a metaanalysis. Schizophr Bull. 2007;33(3):729-36.

59. Yolken RH., Dickerson FB., Fuller Torrey E. Toxoplasma and schizophrenia. Parasite Immunol. 2009;31(11):706-15. doi: 10.1111/j.1365-3024.2009.01131

60. Severance EG., Kannan G., Gressitt KL., Xiao J., Alaedini A., Pletnikov MV., Yolken RH. Anti-gluten immune response following Toxoplasma gondii infection in mice. PLoS One. 2012;7(11):e50991

61. Nemani $\mathrm{K}$ et al.. Schizophrenia and the gut-brain axis. Prog Neuro-Psychoph. 2015; 56:155-166.

62. Hornig $M$, The role of microbes and autoimmynity in the pathogenesis of neuropsychiatric illness. Curr. Opin. Rheumatol. 2013; 25(4): 488-795.

63. Cryan JF., Dinan TG.. Mind-altering microorganisms: the impact of the gut microbiota on brain and behaviour. Nat Rev Neurosci. 2012;13(10):701-12.

64. Caminero A., Herrán AR., Nistal E., Pérez-Andrés J., Vaquero L., Vivas S. et al. .Diversity of the cultivable human gut microbiome involved in gluten metabolism: isolation of microorganisms with potential interest for coeliac disease. EMS Microbiol Ecol. 2014;88(2):309-19.

65. Hong S.N. and Rhee P. L. Unraveling the ties between irritable bowel syndrome and intestinal microbiota. World J. Gastroenterol. 2014; 20: 2470-2481.

66. Kau AL., Ahern PP., Griffin NW., Goodman AL., Gordon JI. Human nutrition, the gut microbiome and the immune system. Nature. 2011;474(7351):327-36. .

67. David LA., Maurice CF., Carmody RN., Gootenberg DB., Button JE., Wolfe BE et al. Diet rapidly and reproducibly alters the human gut microbiome. Nature. 2014 23;505(7484):559-63.

68. Brown K., DeCoffe D., Molcan E., Gibson DL. Diet-induced dysbiosis of the intestinal microbiota and the effects on immunity and disease. Nutrients 2012; 4: 1095-1119

69. Severance E.G., Prandovszky E., Castiglione J., Yolken R.H. Gastroenterology issues in schizophrenia: why the gut matters Curr Psychiatry Rep. 2015; 17(5): 27

70. Kostic A.D., Xavier R.J., Gevers D. The Microbiome in Inflammatory Bowel Diseases: Current Status and the Future Ahead. Gastroenterology. 2014 ; 146(6): 1489-1499.

71. Gevers D., Kugathasan S., Denson LA., Vázquez-Baeza Y., Van
Treuren W., Ren B., Schwager E. et al. The treatment-naïve microbiome in new-onset Crohn's disease. Cell Host Microbe. 2014;12: 15(3): 382-392.

72. Diaz Heijtz R., Wang S., Anuar F., Qian Y., Björkholm B., Samuelsson A., Hibberd ML., Forssberg H., Pettersson S. Normal gut microbiota modulates brain development and behavior. Proc Natl Acad Sci U S A. 2011;108(7):3047-52.

73. Clarke G1, Grenham S., Scully P., Fitzgerald P., Moloney RD., Shanahan F., Dinan TG, Cryan JF. The microbiome-gut-brain axis during early life regulates the hippocampal serotonergic system in a sex-dependent manner. Mol Psychiatry. 2013;18(6):666-73.

74. Sudo N., Chida Y., Aiba Y., Sonoda J., Oyama N., Yu XN. et al.. Postnatal microbial colonization programs the hypothalamicpituitary-adrenal system for stress response in mice. J. Physiol. 2004; 558: 263-275.

75. Dickerson FB., Stallings C., Origoni A., Katsafanas E. et al. Effect of Probiotic Supplementation on Schizophrenia Symptoms and Association With Gastrointestinal Functioning: A Randomized, Placebo-Controlled Trial Prim Care Companion CNS Disord. 2014; 16(1): pii: PCC.13m01579. doi: 10.4088/PCC.13m01579.

76. Severance EG., Dickerson FB., Halling M., Krivogorsky B., Haile L., Yang S. et al. Subunit and whole molecule specificity of the antibovine casein immune response in recent onset psychosis and schizophrenia. Schizophr Res. 2010;118(1-3):240-7.

77. Fernandez-Feo M., Wei G., Blumenkranz G., Dewhirst FE., Schuppan D., Oppenheim FG. et al. The cultivable human oral gluten-degrading microbiome and its potential implications in coeliac disease and gluten sensitivity. Clin Microbiol Infect. 2013 ;19(9):E386-94.

78. Zioudrou C., Streaty R.A., Klee W.A. Opioid peptides derived from foodproteins.Theexorphins.J.Biol.Chem. 1979;254:2446-2449.

79. Teschemacher H. Opioid receptor ligands derived from food proteins. Curr.Pharm.Des. 2003; 9:1331-1344.

80. Bressan P., Kramer P.. Bread and Other Edible Agents of Mental Disease. Front Hum Neurosci. 2016;10:130.

81. Margules D.L. $\beta$-endorphinandendoloxone: hormonesoftheautonomic nervous system for the conservation or expenditure of bodily resources and energy inanticipation off amineorfeast. ActaDiabetol. 1979; 3:155-162.

82. Margules D. L. "Energy balance and opioid receptors: epsilons in the periphery promote conservation; $\kappa$ and $\delta$ in the CNS permit expenditures," in The Eating Disorders: Medical and Psychological Bases of Diagnosis and Treatment, eds B.J. Blinder ,B.F. Chaitinand R.S. Goldstein.New York, NY: PMA Publishing. 1988;21-27.

83. Yeomans M. R., and Gray R. W. Opioid peptides and the control of human ingestive behaviour. Neurosci. Biobehav. Rev. 2002;26:713-728.

84. Kostyra E., Sienkiewicz-Szlapka E., Jarmolowska B., Krawczuk S., and Kostyra H.. Opioid peptides derived from milk proteins. Pol. J. Food Nutr. Sci. 2004; 13:25-35.

85. Miner-Williams W. M., Stevens B. R., and Moughan P. J.Are intact peptides absorbed from the healthy gut in the adult human? Nutr. Res. Rev. 2014;27:308-329.

86. Ulluwishewa D., Anderson R. C., McNabb W. C., Moughan P. J., Wells J. M., and Roy N. C. Regulation of tight junction permeability by intestinal bacteria and dietary components. J. Nutr. 2011;141:769-776.

87. Purohit V., Bode J.C., Bode C., Brenner D.A., Choudhry M.A., Hamilton F., et al. Alcohol, intestinal bacterial growth, intestinal permeability to endotoxin and medical consequences: summary of a symposium. Alcohol. 2008; 42:349-361.

88. Smale S., and Bjarnason I. Determining small bowel integrity 
following drug treatment. Br. J. Clin. Pharmacol. 2003; 56:284-291.

89. Hemmings W.A. The entry into the brain of large molecules derived from diet ary protein.Proc.R.Soc.Lond.B.Biol.Sci. 1978;200:175-192.

90. Sun Z., and Cade J. R. A peptide found in schizophrenia and autism causes behavioral changes in rats. Autism. 1999; 3:85-95.

91. Meisel H., and FitzGerald R. J. Opioid peptides encrypted in intact milk protein sequences. Br. J. Nutr. 2000;84:S27-S31.

92. Hole K., Bergslien H., Jørgensen H. A., Berge O. G., Reichelt K. L., and Trygstad O. E. A peptide-containing fraction in the urine of schizophrenic patients which stimulates opiate receptors and inhibits dopamine uptake. Neuroscience 1979; 4: 1883-1893.

93. Drysdale A., Deacon R., Lewis P., Olley J., Electricwala A., and Sherwood R. A peptide-containing fraction of plasma from schizophrenic patients which binds to opiate receptors and induces hyper-reactivity in rats. Neuroscience. 1982;7:1567-1573.

94. Sokolov O., Kost N., Andreeva O., Korneeva E., Meshavkin V., Tarakanova Y., et al. Autistic children display elevated urine levels of bovine casomorphin-7 immunoreactivity. Peptides. 2014;56: 68-71.

95. Cass H., Gringras P., March J., McKendrick I., O’Hare A. E., Owen L., et al. Absence of urinary opioidpeptides In children with autism. Arch.Dis. Child. 2008;93:745-750.

96. Sun Z., Cade J. R., Fregly M. J., and Privette R. M. $\beta$ Casomorphin induces Fos-like immunoreactivity in discrete brain regions relevant to schizophrenia and autism. Autism 1999; 3: 67-83.

97. Cade R., Privette M., Fregly M., Rowland N., Sun Z. J., Zele V., et al. Autism and schizophrenia: intestinal disorders. Nutr. Neurosci. 2000;3: 57-72.

98. Genuis S.J., and Lobo R. A. Gluten sensitivity presenting as a neuropsychiatric disorder. Gastroenterol. Res. Pract. 2014:ID 293206. http://dx.doi.org/10.1155/2014/293206

99. Lister J., Fletcher P. J., Nobrega J. N., and Remington G. Behavioral effects of food-derived opioid-like peptides in rodents: implications for schizophrenia? Pharmacol Biochem Behav. 2015;134:70-8.

100. Emrich HM., Cording C., Pirée S., Kölling A., von Zerssen D., Herz A. Indication of an antipsychotic action of the opiate antagonist naloxone. Pharmakopsychiatr Neuropsychopharmakol. 1977;10(5):265-70

101.Gillberg C., Terenius L., and Lönnerholm G. Endorphin activity in childhood psychosis. Spinal fluid levels in 24 cases. Arch. Gen. Psychiatry. 1985:42:780-783.

102.Lindström L. H., Besev G., Gunne L. M., and Terenius L. CSF levels of receptor-active endorphins in schizophrenic patients: correlations with symptomatology and monoamine metabolites. Psychiatry Res. 1986; 19: 93-100.

103.Lindström LH., Nyberg F., Terenius L., Bauer K., Besev G., Gunne LM., Lyrenäs S., Willdeck-Lund G., Lindberg B. CSF and plasma beta-casomorphin-like opioid peptides in postpartum psychosis. Am J Psychiatry. 1984;141(9):1059-66

104.Severance EG., Gressitt KL., Alaedini A., Rohleder C., Enning F., Bumb JM., Müller JK., Schwarz E., Yolken RH., Leweke FM. IgG dynamics of dietary antigens point to cerebrospinal fluid barrier or flow dysfunction in first-episode schizophrenia. Brain Behav Immun. 2015;44:148-58.

105. Newton KP., Singer SA. Celiac disease in children and adolescents: special considerations. Semin Immunopathol. 2012;34(4):479-96.

106.Food and Drug Administration, HHS. Food labeling: gluten-free labeling of foods. Final rule. Fed Regist. 2013 Aug 5;78(150):47154-79.
107.Potkin SG., Weinberger D., Kleinman J., Nasrallah H., Luchins D., Bigelow L., Linnoila M., Fischer SH., Bjornsson TD., Carman J., Gillin JC., Wyatt RJ.: Wheat gluten challenge in schizophrenic patients. Am J Psychiatry 1981; 138(1208):11.

108.Arroll MA., Wilder L., Neil J.. Nutritional interventions for the adjunctive treatment of schizophrenia: a brief review. Nutr J. $2014 ; 16: 13: 91$

109.Jackson J., Eaton W., Cascella N., Fasano A., Warfel D., Feldman S., Richardson C., Vyas G., Linthicum J., Santora D., Warren KR., Carpenter WT. Jr, Kelly DL.. A gluten-free diet in people with schizophrenia and anti-tissue transglutaminase or anti-gliadin antibodies. Schizophr Res. 2012;140(1-3):262-3.

110.Lurie Y., Landau DA., Pfeffer J., Oren R. Celiac disease diagnosed in the elderly. J Clin Gastroenterol. 2008 ;42(1):59-61.

111.De Santis A., Addolorato G., Romito A., Caputo S., Giordano A., Gambassi G., et al. Schizophrenic symptoms and SPECT abnormalities in a coeliac patient: Regression after a gluten-free diet. Journal of Internal Medicine. 1997; 242:421-423.

112. Eaton WW., Chen LY., Dohan FC. Jr, Kelly DL., Cascella N. Improvement in psychotic symptoms after a gluten-free diet in a boy with complex autoimmune illness. Am J Psychiatry. 2015;172(3):219-21.

113.Lionetti E., Leonardi S., Franzonello C., Mancardi M., Ruggieri M., Catassi C. Gluten Psychosis: Confirmation of a New Clinical Entity. Nutrients. 2015;7(7):5532-9.

114.Hollon J.R., Cureton P.A., Martin M.L., Puppa E.L.L., \& Fasano A. Trace gluten contamination may play a role in mucosal and clinical recovery in a subgroup of diet-adherent non-responsive celiac disease patients. BMC Gastroenterology. 2013;13(1).

115.Dewar DH., Donnelly SC., McLaughlin SD., Johnson MW., Ellis HJ., Ciclitira PJ. Celiac disease: management of persistent symptoms in patients on a gluten-free diet. World J Gastroenterol. 2012;18(12):1348-56.

116.Mukherjee R., Kelly CP., Schuppan D. Nondietary therapies for celiac disease. Gastrointest Endosc Clin N Am. 2012;22(4):811-31

117.Stoven S., Murray JA., Marietta E. Celiac disease: advances in treatment via gluten modification. Clin Gastroenterol Hepatol. 2012;10(8):859-62

\section{Correspondence address}

Joanna Tomaka

I Klinika Psychiatrii, Psychoterapii i Wczesnej Interwencji

Uniwersytet Medyczny w Lublinie

ul. Głuska 1; 20-439 Lublin

email: j.tom@o2.pl

Otrzymano: 15.12 .2016

Zrecenzowano: 28.02.2017

Przyjęto do druku: 09.03.2017 